\title{
Review of Global Trends in Knowledge, Skills, and Abilities (KSA) Frame- works Applicable to Ph.D. Programs in Engineering
}

\section{Mr. Eric Holloway, Purdue University, West Lafayette}

Eric Holloway currently serves as the Senior Director of Industry Research in the College of Engineering at Purdue University, where he focuses on industry research in the College of Engineering.

From 2007-2013, Eric served as the Managing Director and the Director of Instructional Laboratories in the School of Engineering Education at Purdue University. As Director, he was in charge of the building and implementation of the Ideas to Innovation (i2i) Laboratory, which opened in August 2008 and houses classrooms and laboratories used by the 2000 students in Purdue's First-Year Engineering Program. He oversaw the daily operation of the $\mathrm{i} 2 \mathrm{i}$ lab, and was responsible for the personnel, logistics, and technology used in the classroom and labs. Eric also helped build and directed the College of Engineering sponsored Artisan and Fabrication Lab (AFL), which houses a machine shop, carpentry shop, and a prototyping lab used by all students in the College of Engineering for project work. In 2009, he received a New Employee Staff Award of Excellence from the College of Engineering for his work in launching the i2i lab. Eric has served as the university representative on the Haas Technical Education Council, which is committed to developing manufacturing expertise at the high school, trade school, and university level. He received a BSEE from Purdue University in 1992. He has over 15 years of industrial experience, specializing in manufacturing and electronic controls, for which he holds 3 patents. Eric's industrial experience includes positions at Toyota, Cummins, Woodward, and TRW Automotive. He is currently pursuing his PhD in Engineering Education from Purdue, with an expected graduation date of 2020.

\section{Prof. David F. Radcliffe, Swinburne University of Technology}

Dr. Radcliffe's research focuses on the nature of engineering; engineering habits of mind, how engineering knowledge is created and shared and how it is learned especially outside the classroom. Over the past 30 years, he has conducted field research on the practice of engineering design, new product development and innovation in variety of industries, in large and small firms with an emphasis on design thinking, most recently in relation to sustainability. He also studies engineering education as a complex system, and the design and evaluation of next generation learning environments. This research is intrinsically multidisciplinary and draws on methodologies from the humanities, social and behavioral sciences and involves collaboration with anthropologists, learning scientists, librarians, designers, and architects. 


\title{
Review of Global Trends in Knowledge, Skills, and Abilities (KSA) Frameworks Applicable to Ph.D. Programs in Engineering
}

\begin{abstract}
Lists of desired knowledge, skills, and abilities (KSA) are widespread in undergraduate engineering programs (e.g., ABET Criteria 3; NAE Engineer of 2020 list of student attributes; ASEE's TUEE report). In contrast, such KSA frameworks are less well developed in engineering graduate programs in the US. While some reviews of graduate education over the past decade have emphasized its traditional role of maintaining the pipeline of students for the professoriate, i.e., as future "stewards of the discipline," other reports have stressed the need to foster the development of broader professional skills in graduate students with a view to possible careers outside of the academy, especially in industry. This paper presents a critical review of the different ways these broader KSAs of Ph.D. graduates have been characterized and explores the potential application of such frameworks to engineering graduate programs. The paper draws on reports from Australia, Canada, Europe and the UK on the professional development of graduate students as well as some from the US. As occurs with KSA frameworks for undergraduate programs, the objective is to align expectations of all the stakeholders (e.g., students, industry, academics, universities, and government). However, in the context of graduate programs, these are presented in less prescriptive terms. Relationships between particular training programs and types of experiences as graduate students and the attainment of specific knowledge, skills, and abilities are less clear and reliable methods to measure the outcomes are still very much in their infancy. As most of the frameworks were developed for Ph.D.s in general, and in non-US settings, some adaptation is required when applying to local engineering graduate programs.
\end{abstract}

Tags: graduate programs, frameworks, knowledge, skills, abilities

\section{Introduction}

Knowledge, skills, and abilities (KSA) frameworks are typically developed in engineering education to help educators know what outcomes their students need to meet as they progress toward graduation. In undergraduate engineering education in the US, these KSA frameworks are plentiful (e.g., ABET Criteria 3; NAE Engineer of 2020 list of student attributes; ASEE's TUEE report). In contrast, such frameworks are much less common in graduate engineering education. Yet as the call for change in the undergraduate engineering outcomes brought about the KSA frameworks for undergraduate engineering educators, similar calls for change across the globe are now being issued for graduate student outcomes. Thus far, there has not been the widespread development of graduate engineering KSA frameworks. The major exception is the very comprehensive Vitae Research Development Framework [1] developed in the UK, which is similar to the undergraduate KSA frameworks and has interesting potential applications in the US.

This paper opens with a review of the best known undergraduate KSA frameworks in the US, providing both a context and a history of how these KSA frameworks came to be and how they have evolved over time. As these frameworks are familiar to most faculty in the US not least because of ABET accreditation, they provide a common reference point for thinking about comparable KSA frameworks for graduate programs, especially Ph.D. programs. This is followed by a survey of reports over the past decade calling for reform of the doctorate in the 
US, Canada, UK, Europe, and Australia with a focus on being more explicit about developing broader graduate attributes. We explore in some detail the Researcher Development Framework (RDF), or Vitae, developed by the Careers Research and Advisory Centre in the UK; its elements, how it was validated, and how it is utilized. For example, the Vitae framework "articulates the knowledge, behaviors, and attributes of successful researchers" [1] as a basis for guiding graduate students to customize a unique professional development program based on their individual background, experiences, and career aspirations. It recognizes that each facet or dimension in the framework has multiple levels of attainment which are achieved progressively over time. Finally, the paper discusses the issues for graduate programs in engineering in the US related to adopting or adapting frameworks like the Vitae RDF as a mechanism for being more explicit and consistent in developing broader graduate attributes in Ph.D.s.

\section{Undergraduate Knowledge, Skills and Abilities Frameworks}

Over the past two decades, several undergraduate engineering KSA frameworks have been developed. Three of the most common frameworks, including ABET's accreditation criteria, National Academy of Engineering's (NAE's) Engineer of 2020, and ASEE's TUEE report, are reviewed in detail below. These frameworks all have common characteristics, in that each focuses on student outcomes, and each was generated by surveying a combination of industry experts, academics, and other stakeholders to arrive at a consensus on the appropriate professional outcomes for engineering graduates from baccalaureate programs. The frameworks also share many of the same student outcome characteristics, with a particular focus on problemsolving, communication, and teamwork. Arguably the most influential these frameworks have been the ABET accreditation criteria, reviewed next.

\subsection{ABET Accreditation Criteria}

In 1997, ABET, a non-profit, non-governmental organization that accredits engineering and other programs at the bachelor and master degree level, established eleven student outcomes in what is known as EC2000 [2]. These outcomes are listed below:

a) an ability to apply knowledge of mathematics, science, and engineering.

b) an ability to design and conduct experiments, as well as to analyze and interpret data

c) an ability to design a system, component, or process to meet desired needs within realistic constraints such as economic, environmental, social, political, ethical, health and safety, manufacturability, and sustainability

d) an ability to function on multidisciplinary teams

e) an ability to identify, formulate, and solve engineering problems

f) an understanding of professional and ethical responsibility

g) an ability to communicate effectively

h) the broad education necessary to understand the impact of engineering solutions in a global, economic, environmental, and societal context

i) a recognition of the need for, and an ability to engage in life-long learning

j) a knowledge of contemporary issues

k) an ability to use the techniques, skills, and modern engineering tools necessary for engineering

Following an iterative process of review and consultation, ABET has adopted a revised list of just seven outcomes [3] which will take effect in the 2019-20 accreditation cycle. 
1) an ability to identify, formulate, and solve complex engineering problems by applying principles of engineering, science, and mathematics

2) an ability to apply engineering design to produce solutions that meet specified needs with consideration of public health, safety, and welfare, as well as global, cultural, social, environmental, and economic factors

3) an ability to communicate effectively with a range of audiences

4) an ability to recognize ethical and professional responsibilities in engineering situations and make informed judgments, which must consider the impact of engineering solutions in global, economic, environmental, and societal contexts

5) an ability to function effectively on a team whose members together provide leadership, create a collaborative and inclusive environment, establish goals, plan tasks, and meet objectives

6) an ability to develop and conduct appropriate experimentation, analyze and interpret data, and use engineering judgment to draw conclusions

7) an ability to acquire and apply new knowledge as needed, using appropriate learning strategies.

The EC2000 criteria were initiated in August 1994. 58 invited guests, including guests from the ABET Engineering Accreditation Commission board, several of the professional engineering societies, and many academic institutions and industrial firms, participated in a two-day workshop with the goal of "develop[ing] a simple non-adversarial accreditation process grounded in the philosophy of continuous quality improvement, that is efficient and productive for all volunteers, and for institutions seeking accreditation" [4]. This lead to the eventual output of the EC2000 criteria and the a-k student outcomes.

At the time, these outcomes were considered revolutionary [5]. The EC2000 criteria changed the accreditation process to focus on student outcomes rather than a rigid and prescriptive process of educating undergraduate engineers [5]. The focus on outcomes also made up for skills gaps in engineering graduates that were perceived by industry [5], such as teamwork and communication skills. Once the EC2000 criteria were instituted, US engineering institutions began to implement it, and large changes swept through the undergraduate curriculum [5].

The impacts of EC2000 have been significant. In a study that assessed graduates from before EC2000 and after, graduates in 2004 were shown to be better prepared in all nine outcomes that were assessed compared to graduates in 1994, especially in understanding societal and global issues, ability to apply engineering skills, teamwork skills, and understanding of ethics and professional issues [6]. This was attributed to the fact that "improvements in student learning have indeed resulted from changes in engineering program curricula, teaching methods, faculty practices, and student experiences inside and outside the classroom" [6] brought about by the implementation of EC2000.

Work on the newly approved Criteria 3 was initiated in 2009 with the creation of the Criterion 3 task force within the EAC Criteria Committee. Members of the task force were made up of members of the EAC Criteria Committee, domestic undergraduate and graduate engineering 
programs, industry, and professional societies. The task force examined the existing a-k outcomes for shortcomings based on feedback from stakeholders and other interested parties and determined seven high-level topic areas that would be addressed by the new criteria [7]. Through a process of iteration with feedback from a variety of stakeholder groups, the new Criteria 3 was adopted in April 2017.

The EAC Criteria Committee justified the creation of new Criteria 3 for several reasons. First, ABET felt that EC2000 criteria were getting old, as it had not been reviewed since the mid1990s [7]. Second, after receiving feedback from stakeholders, EAC Criteria Committee identified shortcomings in all 11 of the a-k outcome of the EC2000 criteria [7]. These shortcoming included: "programs had the most difficulty determining the extent of outcome attainment with components 3(d) (ability to function on multidisciplinary teams), 3(f) (understanding of professional and ethical responsibility), 3(h) (a broad education to understand engineering solutions in global, economic, environmental, and societal context), 3(i) (recognition of the need for and ability to engage in life-long learning), and 3(j) (knowledge of contemporary issues)" [7]. Finally, the EAC Criteria Committee "concluded that some of the (a)-(k) components were interdependent, broad and vague in scope, or impossible to measure" [7].

ABET consider the new Criteria 3 outcomes "richer and measurable, but above all realistic" [7]. While the mapping EC2000 criteria to the new Criteria 3 is not straightforward, ABET provides a map summary for engineering programs (http://www.abet.org/wpcontent/uploads/2018/03/C3_C5_mapping_SEC_1-13-2018.pdf). In summary, it is anticipated that the changes based on the new Criteria 3 will be easier for engineering programs to adapt to as the new Criteria 3 remains focused on outcomes, which was the big change when EC2000 criteria were implemented.

\subsection{NAE Engineer of 2020}

NAE's report The Engineer of 2020: Visions of Engineering in the New Century [8], spurred by rapid technological changes and a global economy, identified several issues with undergraduate engineering education in the US. One of the highlights of this report was a list of attributes that graduating engineers will need to have by 2020. The NAE report The Engineer of 2020 [8] lists the following attributes as important for the engineer of the future:

- $\quad$ strong analytical skills

- practical ingenuity

- creativity

- communication

- business and management

- leadership

- $\quad$ high ethical standards and professionalism

- dynamism, agility, resilience, and flexibility

- lifelong learners

This report was developed by an 18-member steering committee over the course of a year that began in fall 2002, focused on "development of a vision for engineering and the work of the engineer in 2020" [8]. The committee was made up mostly of participants from higher education, but also included representatives from industry and government. The committee met four times 
over the course of a year and published the report in 2004. This report led to next stage, which was how to educate the Engineer of 2020, and resulted in the NAE publication of Educating the Engineer of 2020: Adapting Engineering Education to the New Century [9]. This publication was referenced as one of the several major publications reviewed by EAC Criteria Committee for desired attributes of engineers during the formation of the new ABET Criteria 3 [7]. In addition, some universities such as Purdue University implemented their own version of the Engineer of 2020 [10], resulting in new educational opportunities for students such as an engineering leadership minor.

\subsection{ASEE Transforming Undergraduate Education in Engineering (TUEE) KSAs}

The American Society for Engineering Education (ASEE) in 2013 launched an initiative called Transforming Undergraduate Education in Engineering which "aims to produce a clear understanding of the qualities engineering graduates should possess and to promote changes in curricula, pedagogy, and academic culture needed to instil those qualities in the coming generation of engineers" [11]. In support of this goal, a series of multi-year workshops were held "that ultimately will produce a flexible framework for transforming the undergraduate engineering experience" [11]. The first workshop was held in May 2013 consisting of representatives from academia, industry, and government "in an intensive exploration of the knowledge, skills, and abilities needed in engineering today and in the coming years" [11]. The outcome of this meeting is a report that lists the $36 \mathrm{KSAs}$ that were considered most important, including identifying 15 of the 36 KSAs as "High Priority", meaning a priority in terms of engineering reform. Finally, responsibility for the development of each KSA listed in the report is assigned to a combination of the following: students; parents; academia; industry; and other. A list of the 36 KSAs [11], including the "High Priority" (in bold) and "Important" (in italics), and shown in Tables 1-3, Knowledge, Skills and Abilities respectively.

Table 1: TUEE Knowledge Areas

\begin{tabular}{|c|c|}
\hline Number & Knowledge Area \\
\hline KSA 2 & Physical sciences and engineering science fundamentals \\
\hline KSA 4 & Systems integration \\
\hline KSA 7 & $\begin{array}{l}\text { Cultural awareness in the broad sense: nationality, ethnicity, linguistic, gender, sexual } \\
\text { orientation }\end{array}$ \\
\hline KSA 8 & Economics and business acumen \\
\hline KSA 18 & Informational technology - IT \\
\hline KSA 21 & Security knowledge: cyber, data, etc. \\
\hline KSA 34 & Understanding of design \\
\hline KSA 35 & Conflict resolution \\
\hline KSA 17 & Public safety \\
\hline
\end{tabular}

Table 2: TUEE Skills

\begin{tabular}{ll}
\hline Number & Skill \\
\hline KSA 1 & Good communication skills \\
KSA 3 & Ability to identify, formulate, and solve engineering problems \\
KSA 10 & Critical thinking \\
KSA 12 & Ability to prioritize efficiently \\
KSA 13 & Project management: supervising, planning, scheduling, budgeting, etc. \\
KSA 16 & $\begin{array}{l}\text { Ability to use new technology and modern engineering tools necessary for engineering } \\
\text { practice }\end{array}$
\end{tabular}




\begin{tabular}{ll}
\hline Number & Skill \\
\hline KSA 19 & $\begin{array}{l}\text { Applied knowledge of engineering core sciences and implementation skills to apply them in the } \\
\text { real world }\end{array}$ \\
KSA 20 & Data interpretation and visualization \\
KSA 22 & Leadership \\
KSA 24 & Systems thinking \\
KSA 26 & Application-based research and evaluation skills \\
KSA 27 & Ability to create a vision \\
KSA 29 & Mentoring skills \\
KSA 31 & Ability to deal with ambiguity and complexity \\
\hline
\end{tabular}

Table 3: TUEE Abilities

\begin{tabular}{|c|c|}
\hline Number & Abilities \\
\hline KSA 5 & Curiosity and persistent desire for continuous learning \\
\hline KSA 6 & Self-drive and motivation \\
\hline KSA 9 & $\begin{array}{l}\text { High ethical standards, integrity, and global, social, intellectual, and technological } \\
\text { responsibility }\end{array}$ \\
\hline KSA 11 & Willingness to take calculated risk \\
\hline KSA 14 & Teamwork skills and ability to function on multidisciplinary teams \\
\hline KSA 15 & Entrepreneurship and intrapreneurship \\
\hline KSA 23 & Creativity \\
\hline KSA 25 & Emotional intelligence \\
\hline KSA 28 & Good personal and professional judgment \\
\hline KSA 30 & Flexibility and the ability to adapt to rapid change \\
\hline KSA 32 & Innovation \\
\hline KSA 33 & Technical intuition/metacognition \\
\hline KSA 36 & Ownership and accountability \\
\hline
\end{tabular}

The next stage of TUEE KSA development will be a Phase IV report due in mid-2018 that will focus on narrowing the list of KSAs to a set of competencies that can be affected through curricular and pedagogical changes and how professional societies can assist.

\subsection{Comparison of Undergraduate KSA Frameworks}

Since the "Mann Report" in 1918 [12], undergraduate education in the US has constantly evolved to respond to the demands on the time. The three undergraduate KSA frameworks reviewed here are further examples of that evolution. While these three KSA frameworks have more in common than not, such as the similar methods in which the frameworks were generated and the sharing of many of the same student outcomes, the frameworks are not without differences. Table 4 below summarizes the observed commonalities and differences between the frameworks. 
Table 4: Undergraduate KSA Framework Commonalities and Differences

\begin{tabular}{|c|c|c|}
\hline Framework & Differences & $\begin{array}{l}\text { Commonalities of All } \\
\text { Frameworks }\end{array}$ \\
\hline 1. ABET EC2000 a-k & $\begin{array}{l}\text { EC2000 a-k is more than a list of } \\
\text { attributes, tries to give some context. }\end{array}$ & $\begin{array}{l}\text { 1. Similar methods in which the } \\
\text { frameworks were generated. }\end{array}$ \\
\hline 2. ABET Criteria 3 & $\begin{array}{l}\text { Criteria } 3 \text { goes to the next level in } \\
\text { providing context. } \\
\text { Note: for both ABET lists, almost } \\
\text { everything is an "ability". }\end{array}$ & $\begin{array}{l}\text { 2. Sharing of many of the same } \\
\text { student outcomes (problem- } \\
\text { solving, communication, and } \\
\text { teamwork). }\end{array}$ \\
\hline 3. Engineer of 2020 & $\begin{array}{l}2020 \text { list is short and concise, trade- } \\
\text { off with no context, which is } \\
\text { assumed. Pushes attributes beyond } \\
\text { ABET. }\end{array}$ & $\begin{array}{l}\text { 3. Have successfully brought } \\
\text { about change in the curriculum } \\
\text { (except TUEE which is brand } \\
\text { new). }\end{array}$ \\
\hline 4. ASEE TUEE & $\begin{array}{l}\text { TUEE differentiates between } \\
\text { knowledge, skills, and abilities } \\
\text { (although many are still "abilities". } \\
\text { Prioritizes list. }\end{array}$ & \\
\hline
\end{tabular}

\section{Survey of Proposals Globally for Reform of the Doctorate}

Similar to concerns voiced in the past about engineering outcomes for undergraduates, globally there have been concerns raised over the past decade around the outcomes for engineering graduate students, particularly Ph.D. candidates, especially with regard to preparedness for professional practice. Voices from the US, Canada, Europe, and Australia have weighed in regarding some of the $\mathrm{Ph} . \mathrm{D}$. student outcomes that are lacking in graduates, and are reviewed below.

\subsection{USA}

The Council of Graduate Schools and Educational Testing Service issued a joint report on an improved system of graduate education, The Path Forward [13]. While recognizing the historical strengths of graduate programs built around master's education, which do tend to include significant professional development, and the value of in-depth research training at the doctoral level, the report highlighted the absence of a strong professional development component in doctoral programs. The report argued that it is vital for graduate programs to provide more understanding of and preparation for career pathways beyond the academy to remain competitive. It was also important to recognize and respond to demands from industry for Ph.D. graduates to acquire transferable professional skills.

Such professional development programs as part of doctoral programs should:

- Encourage the development of creativity and entrepreneurship in conjunction with core disciplinary attributes.

- Improve personal effectiveness including self-organization and career development skills.

- Develop capacity for project management, understanding of finance, funding and resource management.

- Cultivate a highly-developed framework of professional and research ethics.

- Encourage the development of skills that enhance research impact, including communication, teamwork, relating work to a broader context, and application of research to larger corporate or social purposes. 
This report draws attention to the Vitae program as being the state of the art in terms of supporting the development of the personal, professional and career development of researchers. While the emphasis in The Path Forward is on developing career pathway options for graduate students beyond the academy, this does not negate the need for doctoral graduate programs to produce sufficient stewards of the disciplines [14].

\subsection{Canada}

Recognizing that less than $20 \%$ of Ph.D. graduates are employed as full-time university professors, the Conference Board of Canada published a report, Inside and Outside the Academy: Valuing and Preparing Ph.D.s for Careers [15]. It explores some of the challenges and barriers that Ph.D. graduates face when transitioning to careers and makes recommendations on how to better prepare graduates of a variety of potential career pathways.

The focus is on encouraging graduate students to engage with professional development resources (e.g., workshops, courses, and supplementary online materials) from early on in their studies, ensuring they have time to build a professional network and are encouraged to explore various career options. The need for individual career advising and for programs designed to suit particular disciplines are emphasized. The value of experiential learning opportunities such as internships or co-op programs in industry linked to their research is highlighted as a relatively low-cost way for employers to "try out" Ph.D. students. The Mitacs-Accelerate program (https://www.mitacs.ca/en/programs/accelerate) is seen as an exemplar of this approach.

\subsection{Australia}

In 2016, the Australian Council of Learned Academies (ACOLA) published a review of the training needs for graduate students [16]. This covered higher degree research students, masters, and Ph.D., across all disciplinary areas. Amongst the recommendations, it called for broader transferable skills development. The report noted that:

"Although many universities have made significant investments in this area, transferable skills development is not as strongly embedded in our research training system as it is in some other comparable research training systems around the world. Skills development must be flexible and candidate directed, and take into account the diverse backgrounds and experience of candidates."

Based on an analysis of submissions from many stakeholders, the report synthesized the following list of desirable 'competencies' in graduates:

- Deep disciplinary knowledge and skills acquired through formal education and training.

- Work experience and workplace awareness through relevant workplace exposure.

- Complex problem solving, critical thinking and flexibility to apply research skills to a variety of environments and situations.

- Interpersonal and communication skills including: writing, oral communication to diverse audiences, teamwork, collaboration, and leadership.

- Resilience, commitment to lifelong learning, and opportunity awareness.

It must be noted that historically Ph.D. programs in Australia required little or no advanced discipline-specific nor research methodology courses. Programs were more in the nature of a 
hands-on apprenticeship in a laboratory whereby students were developed as members of a disciplinary community of practice.

The submissions from industry focused on the transferability of skills from research settings into the workplace, and these fell into three broad categories:

- ability to solve real-world problems in industry

- ability to understand industry needs and drivers

- well-developed communication and interpersonal skills

The ACOLA report recommended that as an established and comprehensive approach, the Vitae Researcher Development Framework provided a useful model that could be adapted for use in Australia. It is worth noting that the national research funding body, the Australian Research Council (similar to NSF) now funds Industrial Transformation Training Centres that support Ph.D. students and postdoctoral fellows to pursue industrial training and thereby enhance research collaboration between universities, national labs, industry, and other organizations. Also, a number of new types of Ph.D. program are now emerging with integral professional development programs including industry internships tailored to the particular outcomes.

\subsection{Europe}

The European University Association (EUA) undertook two sequential investigations into enhancing the graduate outcomes from doctorate education. The EUA Doctoral Programs Project [17] conducted in 2004-05 studied the practices and experiences in doctoral programs in 49 universities across Europe. This baseline study led to the creation of ten principles that should guide doctoral programs [18]. The focus was on diversity and innovation in practices especially as these related to quality experiences, mobility, international collaboration, interdisciplinarity and transferable skills. The follow-up project, DOC-CAREERS [19] explored the perspectives of both industry and universities around creating effective collaborative doctoral programs as a mechanism to promote innovation and to better prepare graduates for careers in industry. It involved 33 universities, 31 companies and 18 other stakeholders across 20 European countries and spanned three research domains; Science, Engineering and Technology (SET), Biotechnology, Medical, Life Sciences (BML) and Economics and Social Sciences (ESS).

The DOC-CAREER project concluded that excellence in research was the hallmark of success and across a diverse range of programs investigated, seven common characteristics emerged, three basic pre-conditions and four main operating conditions that the industry and university partners needed to achieve.

The pre-conditions include a sharing of the intended value of the research, mutual trust and a long-term approach. The operating conditions include suitable provisions for funding, joint supervision of the doctoral candidate, efficient project management and an expectation of good performance in research, eventually leading to a doctoral degree gained according to established academic standards.

The third phase of this series of studies of doctoral education, DOC-CAREER II [20], took place 2006-09 and was focused on promoting collaborative doctoral education to enhance career opportunities. The feature that distinguishes a collaborative doctoral education from a collaborative research project involving graduate students is the participation of industry staff in 
student supervision to a significant extent. It explored more deeply the success factors for collaborative doctoral programs and concluded the following:

On employability, evidence from the study shows that universities, companies and doctoral candidates all considered that doctorate holders who graduated from a collaborative scheme had more job opportunities in the non-academic sector than doctorate holders who graduated from a traditional programme. The ability to be "bilingual", bridging the academic and business sectors, and the development of transferable skills, were identified as the main reasons accounting for the enhanced employment prospects of doctorate holders in the non-academic sector.

\subsection{A Possible Common Link: The Vitae Researcher Development Framework}

In the quest for a similar graduate framework to the undergraduate engineering KSA frameworks that exist, one framework that has been mentioned consistently in these reports about reforming the Ph.D. is the Vitae Researcher Development Framework (RDF). This framework, which has some similarities to the undergraduate engineering KSA frameworks previously reviewed, in that it is a list of attributes that successful Ph.D. graduates should attain during their graduate education in preparedness for professional practice.

\section{Vitae Researcher Development Framework}

The Vitae RDF [1] "is a professional development framework for planning, promoting and supporting the personal, professional and career development of researchers in higher education. It articulates the knowledge, behaviors, and attributes of successful researchers and encourages them to realize their potential" [1].

The RDF "consists of four domains, 12 subdomains and 63 descriptors encompassing the knowledge, intellectual abilities, techniques and professional standards to do research, as well as the personal qualities and skills to work with others and ensure the wider impact of research" [21]. Developed in the United Kingdom (UK) by the Careers Research and Advisory Centre, the RDF has distinct advantages over other KSA frameworks, in that it was rigorously developed using research methods and it applies specifically to engineering graduate research experiences. It is based on a phenomenographic research approach, using semi-structured interviews and focus groups, and utilized cluster analysis to evaluate the data. The RDF was validated by consultations with potential users and other stakeholders, which garnered further changes to the framework. The final version of the RDF was validated by an external independent advisory group of experts [21], and the RDF has been in place since 2011 and adopted by most UK universities [15].

A specific version of the RDF exists that is applied directly to engineering, called the "Engineering Lens" on the Vitae RDF [1], which applies the UK chartered engineering standard to the Vitae RDF. This "Engineering Lens" allows an engineering perspective on each of the 12 subdomains and 63 descriptors. In the US, the Vitae program was referenced as the best government-supported effort "to recognize this deficiency in the traditional research doctoral preparation, and [...] fill this gap" [13]. Table 5 below shows the organization of the 4 domains, 12 subdomains, and 63 descriptors of the Vitae RDF. 
Table 5: Summary of Vitae RDF Domains, Subdomains, and Descriptors [1, 22]

\begin{tabular}{|c|c|c|}
\hline Vitae Domain & Vitae Subdomains & Vitae Descriptors \\
\hline \multirow{2}{*}{$\begin{array}{l}\text { Domain A: Knowledge and } \\
\text { intellectual abilities }\end{array}$} & A1: Knowledge base & 1. Subject knowledge \\
\hline & & $\begin{array}{l}\text { 2. Research methods: theoretical } \\
\text { knowledge }\end{array}$ \\
\hline \multirow{15}{*}{$\begin{array}{l}\text { Definition: The knowledge, } \\
\text { intellectual abilities and } \\
\text { techniques to do research. }\end{array}$} & & $\begin{array}{l}\text { 3. Research methods: practical } \\
\text { application }\end{array}$ \\
\hline & & 4. Information seeking \\
\hline & & $\begin{array}{l}\text { 5. Information literacy and } \\
\text { management }\end{array}$ \\
\hline & & 6. Languages \\
\hline & & $\begin{array}{l}\text { 7. Academic literacy and } \\
\text { numeracy }\end{array}$ \\
\hline & A2: Cognitive abilities & 8. Analyzing \\
\hline & & 9. Synthesizing \\
\hline & & 10. Critical thinking \\
\hline & & 11. Evaluating \\
\hline & & 12. Problem solving \\
\hline & A3: Creativity & 13. Inquiring mind \\
\hline & & 14. Intellectual insight \\
\hline & & 15. Innovation \\
\hline & & 16. Argument construction \\
\hline & & 17. Intellectual risk \\
\hline \multirow{3}{*}{$\begin{array}{l}\text { Domain B: Personal } \\
\text { Effectiveness }\end{array}$} & B1: Personal qualities & 18. Enthusiasm \\
\hline & & 19. Perseverance \\
\hline & & 20. Integrity \\
\hline \multirow{14}{*}{$\begin{array}{l}\text { Definition: The personal } \\
\text { qualities and approach to } \\
\text { be an effective researcher. }\end{array}$} & & 21. Self-confidence \\
\hline & & 22. Self-reflection \\
\hline & & 23. Responsibility \\
\hline & B2: Self-management & 24. Preparation and prioritization \\
\hline & & 25. Commitment to research \\
\hline & & 26. Time management \\
\hline & & 27. Responsiveness to change \\
\hline & & 28. Work-life balance \\
\hline & B3: Professional and career & 29. Career management \\
\hline & development & $\begin{array}{l}\text { 30. Continuing professional } \\
\text { development }\end{array}$ \\
\hline & & 31. Responsiveness to \\
\hline & & opportunities \\
\hline & & 32. Networking \\
\hline & & 33. Reputation and esteem \\
\hline \multirow{3}{*}{$\begin{array}{l}\text { Domain C: Research } \\
\text { governance and organization }\end{array}$} & C1: Professional conduct & 34. Health and safety \\
\hline & & $\begin{array}{l}\text { 35. Ethics, principles, and } \\
\text { sustainability }\end{array}$ \\
\hline & & 36. Legal requirements \\
\hline \multirow{4}{*}{$\begin{array}{l}\text { Definition: The knowledge } \\
\text { of the standards, requirements, } \\
\text { and professionalism to do } \\
\text { research }\end{array}$} & & 37. IPR and copyright \\
\hline & & 38. Respect and confidentiality \\
\hline & & 39. Attribution and co-authorship \\
\hline & & 40. Appropriate practice \\
\hline
\end{tabular}




\begin{tabular}{|c|c|c|}
\hline Vitae Domain & Vitae Subdomains & Vitae Descriptors \\
\hline & C2: Research management & 41. Research strategy \\
\hline & & 42. Project planning and delivery \\
\hline & & 43. Risk management \\
\hline & C3: Finance, funding, and & 44. Income and funding \\
\hline & resources & generation \\
\hline & & 45. Financial management \\
\hline & & 46. Infrastructure and resources \\
\hline Domain D: Engagement, & D1: Working with others & 47. Collegiality \\
\hline influence and impact & & 48. Team working \\
\hline & & 49. People management \\
\hline \multirow{14}{*}{$\begin{array}{l}\text { Definition: The knowledge } \\
\text { and skills to work with } \\
\text { others and ensure the wider } \\
\text { impact of research. }\end{array}$} & & 50. Supervision \\
\hline & & 51. Mentoring \\
\hline & & 52. Influence and leadership \\
\hline & & 53. Collaboration \\
\hline & & 54. Equality and diversity \\
\hline & D2: Communication and & 55. Communication methods \\
\hline & dissemination & 56. Communication media \\
\hline & & 57. Publication \\
\hline & D3: Engagement and impact & 58. Teaching \\
\hline & & 59. Public engagement \\
\hline & & 60. Enterprise \\
\hline & & 61. Policy \\
\hline & & 62. Society and culture \\
\hline & & 63. Global citizenship \\
\hline
\end{tabular}

The definition and context of the knowledge, skills, and abilities utilized by the Vitae RDF have particular meaning when applied to engineering graduate research experiences as the Vitae RDF has provided distinct definitions for each of the four Vitae RDF domain definitions. These definitions, which are listed in Table 5 above, when combined provide a clear definition of the KSAs that engineering graduate researchers should aspire to during their graduate research experience, summarized as follows:

The knowledge, intellectual abilities, and techniques to do research; the personal qualities and approach to be an effective researcher; the knowledge of the standards, requirements, and professionalism to do research; the knowledge and skills to work with others and ensure the wider impact of research [1].

Another benefit of the Vitae RDF is that each dimension in the framework has multiple levels of attainment which are achieved progressively over time. The Vitae RDF accomplishes this by having each of the 63 descriptors "contains between three to five phases, representing distinct stages of development or levels of performance within that descriptor" [1]. For example, the phases for A2: Cognitive abilities, Descriptor \#12 - Problem Solving are listed below in Table 6. 
Table 6: Vitae RDF Phases for Descriptor \#12 - Problem Solving [1]

\begin{tabular}{lllll}
\hline Descriptor & Phase 1 & Phase 2 & Phase 3 & Phase 4 \\
\hline $\begin{array}{l}\text { Problem } \\
\text { Solving }\end{array}$ & $\begin{array}{l}\text { Isolates basic } \\
\text { themes of own } \\
\text { research; } \\
\text { formulates basic } \\
\text { research } \\
\text { questions and } \\
\text { hypotheses. }\end{array}$ & $\begin{array}{l}\text { Formulates and } \\
\text { applies solutions } \\
\text { to a range of } \\
\text { research } \\
\text { problems and } \\
\text { effectively } \\
\text { analyses and } \\
\text { interprets } \\
\text { research results. }\end{array}$ & $\begin{array}{l}\text { Identifies new } \\
\text { trends, complex } \\
\text { questions and } \\
\text { broader } \\
\text { problems; } \\
\text { designs } \\
\text { substantial } \\
\text { projects. }\end{array}$ & $\begin{array}{l}\text { Leads a research agenda by making } \\
\text { major contributions to understanding. }\end{array}$ \\
& & $\begin{array}{l}\text { Challenges } \\
\text { particular } \\
\text { hypotheses } \\
\text { and refines them } \\
\text { in the light of } \\
\text { results. }\end{array}$ & $\begin{array}{l}\text { Asks the pertinent questions and } \\
\text { designs projects that challenge } \\
\text { traditional thinking in general and } \\
\text { progress research themes. }\end{array}$ \\
& & & \\
& & &
\end{tabular}

Another aspect that makes the Vitae RDF unique is the inclusion of Domain B, focused on personal effectiveness, which includes the sub-domains for personal qualities, self-management, and professional and career development. This domain is typically not included or only lightly focused on in other KSA frameworks, and yet when viewed in context with the other Vitae domains (which are more in line with other KSA frameworks), a more well-rounded perspective can be gained from the Vitae framework.

\section{Discussion}

While momentum is building globally for change in graduate education, including engineering education, the development of suitable KSA frameworks to guide these improvements are in their infancy. The Vitae RDF, rigorously developed and widely used in the UK, seems to be gaining recognition in a number of other countries as a sound basis for reform. Yet implementing a framework like the Vitae RDF in the US may not be straightforward. Major undergraduate engineering education change occurred in the US when ABET accreditation became accepted, and as of now, there is no equivalent for graduate engineering education in the US.

A problematic issue with implementing change in graduate engineering education is that unlike undergraduate programs, graduate education is not curricular or programmatic. Rather, much of the US graduate engineering experience happens during the research experience, in the lab, with other graduate students, and practices vary widely inside and between institutions. The literature around the engineering graduate student research experience indicates that the experience varies greatly depending on things such as the type of research, research group size, access to resources, and relationship to the advisor [23]. While the Vitae RDF has been shown be to be a complete and effective tool in certain contexts, its use as an effective tool has yet been demonstrated in a US engineering education context.

Based on this review, we suggest there are two promising directions for future work. The first is to utilize more of a systematic review process to generate the lists of attributes applies to the undergraduate KSA frameworks. In addition to involving industry experts, academics, and other stakeholders, the development of future KSAs would benefit from a thorough, and systematic review of the literature on the transition to work drawing on a variety of scholarly and research 
communities beyond engineering. Recent studies such as Exploring learning and fit in the transition from higher education to the labour market: A systematic review [24] and What competencies should undergraduate engineering programs emphasize? A systematic review [25] are examples of such reviews.

The second area for future work is around translating existing graduate KSA frameworks to the US context. The proven Vitae RDF seems ready for adoption (perhaps with some adaptation) in at least two scenarios. The first scenario would be a faculty member, department, or school to use it as intended; have students self-assess where they are on each phase of development, identify strengths and weaknesses, and then work on their weakness. The framework seems ready to use for the purpose. The second scenario would be to develop a psychometric assessment utilizing the Vitae RDF assessing all or portions of the framework across a large population of engineering graduate students to gain a broader understanding of engineering graduate students' experiences and outcomes.

\section{Conclusions}

While the programmatic fostering of broad graduate outcomes in the form of desired knowledge, skills, and abilities is well-established practice in undergraduate and masters engineering education in the US, there is no equivalent sector-wide approach in engineering Ph.D. programs. This reflects the fact that the former programs are externally accredited through a process that involves the engineering education community at large. Over the past decade, there has been a growing conversation in the US about the future shape of doctoral education, including consideration of developing broad graduate attributes. However, there seems to be little evidence of systemic change in the structure of engineering Ph.D. programs flowing from this policy conversation. Similar conversations in other jurisdictions including the UK, Europe, Canada and Australia, have led to the creation of quite sophisticated frameworks for developing a broad range of graduate outcomes in Ph.D. programs, the most notable of these being the Vitae Researcher Development Framework. These international developments provide a rich source of innovative ideas and evidence-based practices that can usefully inform reform in the engineering Ph.D. programs in the US.

\section{References}

[1] Vitae. (2011, 9/9/2107). Researcher development framework. Available: https://www.vitae.ac.uk/vitae-publications/rdf-related/researcher-developmentframework-rdf-vitae.pdf/@ @ download/file/Researcher-Development-Framework-RDFVitae.pdf

[2] Engineering Accreditation Commission, "Criteria for accrediting engineering programs," ABET Inc., USA, 2007.

[3] Engineering Accreditation Commission. (2017, Criteria for accrediting engineering programs. Available: http://www.abet.org/wp-content/uploads/2017/11/EAC-Criterion-35-Revisions.pdf

[4] Engineering Accreditation Commission. (1995, The vision for change: A summary report of the ABET/NSF/industry workshops. Available: http://bioinfo.uib.es/ joe/semdoc/PlansEstudis/ABET_Criteria_PTE/Vision.pdf 
[5] Engineering Accreditation Commission. (2004, Sustaining the change: A follow-up report to the vision for change. Available: http://www.abet.org/wpcontent/uploads/2015/05/sustaining-the-change.pdf

[6] J. F. Volkwein, L. R. Lattuca, P. T. Terenzini, L. C. Strauss, and J. Sukhbaatar, "Engineering change: A study of the impact of EC2000," International Journal of Engineering Education, vol. 20, pp. 318-328, 2004.

[7] Engineering Accreditation Commission. (2017). Rationale for revising criteria 3 and 5. Available: http://www.abet.org/accreditation/accreditation-criteria/accreditationalerts/rationale-for-revising-criteria-3/

[8] National Academy of Engineering, The engineer of 2020: Visions of engineering in the new century. Washington, DC: The National Academy Press, 2004.

[9] National Academy of Engineering, Educating the engineer of 2020: Adapting engineering education to the new century. Washington, DC: The National Academies Press, 2005.

[10] J. Jones, P. Meckl, M. Harris, M. Cox, O. Cekic, M. Okos, O. Campanella, N. Houze, J. Litster, and N. Mosier, "Purdue's Engineer Of 2020: The Journey," in American Society for Engineering Education, 2009.

[11] American Society for Engineering Education. (2013). Phase I: Synthesizing and integrating industry perspectives. Available:

https://www.asee.org/TUEE_PhaseI_WorkshopReport.pdf

[12] C. R. Mann, A study of engineering education, prepared for the Joint Committee on Engineering Education of the National Engineering Societies vol. 11. NewYork: The Carnegie Foundation for the Advancement of Teaching, 1918.

[13] C. Wendler, B. Bridgeman, F. Cline, C. Millett, J. Rock, N. Bell, and P. McAllister, "The path forward: The future of graduate education in the United States," Educational Testing Service, 2010.

[14] C. M. Golde and G. E. Walker, Envisioning the future of doctoral education preparing stewards of the discipline - Carnegie essays on the doctorate: San Francisco, CA: JosseyBass, 2006.

[15] J. Edge and D. Munro, "Inside and outside the academy: Valuing and preparing PhDs for careers," in Ottawa ON: The Conference Board of Canada, 2015.

[16] J. McGagh, H. Marsh, M. Western, P. Thomas, A. Hastings, M. Mihailova, and M. Wenham, "Review of Australia's research training system," Australian Council of Learned Academies: Melbourne, Australia, 2016.

[17] European University Association. (2005, Jan 2, 2018). Doctoral programmes for the European knowledge society: report on the EUA doctoral programmes project. Available: http://www.eua.be/eua/jsp/en/upload/Doctoral_Programmes_Project_Report.1129278878 120.pdf

[18] European University Association. (2005, Jan 2, 2018). Conclusions and recommendations: Bologna seminar on "Doctoral programmes for the European knowledge society. Available: http://www.eua.be/eua/jsp/en/upload/Salzburg_Conclusions.1108990538850.pdf

[19] L. Borrell-Damian. (2009, Jan 2, 2018). Collaborative doctoral education: Universityindustry partnerships for enhancing knowledge exchange. Available: http://eua.be/activities-services/news/newsitem/2015/06/18/EUA_launches_DOCCAREERS_II_project_report.aspx 
[20] L. Borrell-Damian, R. Morais, and J. H. Smith. (2015, Jan 2, 2018). Collaborative doctoral education in Europe: Research partnerships and employability for researchers Available: http://eua.be/activitiesservices/news/newsitem/2015/06/18/EUA_launches_DOCCAREERS_II_project_report.aspx

[21] J. Reeves, P. Denicolo, J. Metcalfe, and J. Roberts, "The vitae researcher development framework and researcher development statement: Methodology and validation report," Careers Research \& Advisory Centre (CRAC) Ltd2012.

[22] Vitae. (2014, 9/9/2107). Engineering lens on the vitae researcher development framework and the engineering council's UK standard for professional engineering competence. Available: https://www.vitae.ac.uk/vitae-publications/rdfrelated/engineering-lens-on-the-vitae-researcher-development-framework-rdf2012.pdf/@@download/file/Engineering-Lens-on-the-Vitae-Researcher-DevelopmentFramework-RDF-2014.pdf

[23] E. Crede and M. Borrego, "Learning in graduate engineering research groups of various sizes," Journal of Engineering Education, vol. 101, pp. 565-589, 2012.

[24] I. Grosemans, L. Coertjens, and E. Kyndt, "Exploring learning and fit in the transition from higher education to the labour market: A systematic review," Educational Research Review, 2017.

[25] H. J. Passow and C. H. Passow, "What competencies should undergraduate engineering programs emphasize? A systematic review," Journal of Engineering Education, vol. 106, pp. 475-526, 2017. 